Studia nad Autorytaryzmem i Totalitaryzmem 43, nr 3

Wrocław 2021

https://doi.org/10.19195/2300-7249.43.3.26

\author{
ALEKSANDRA SZYMAŃSKA \\ ORCID: 0000-0003-0569-3005 \\ Uniwersytet Wrocławski \\ aleksandra.kaczmarczyk@uwr.edu.pl
}

\title{
Tyrania cicha i zawoalowana według traktatu De tyranno Bartolusa de Saxoferrato
}

\author{
Slowa kluczowe: tyrania, tyran, tyrania cicha i ukryta, Bartolus de Saxoferrato, opera tyran- \\ nica, traktat.

\section{TACIT AND VEILED TYRANNY ACCORDING TO THE TREATISE DE TYRANNO BY BARTOLUS DE SAXOFERRATO}

\begin{abstract}
The paper is devoted to the tacit and veiled tyranny, a concept developed by Bartolus de Saxoferrato in his treatise On the Tyrant (De tyranno), widely regarded as an outstanding representative of the commentator school. In addition to his strictly legal work, which consists of commentaries on individual parts of the Corpus iuris civilis, he is also the author of political and legal treatises, dealing with important topics for the inhabitants of late medieval Italy. In the treatise, he decided to discuss in detail the theme of tyranny from the perspective of a jurist interested in solving the concrete problems that tyrant rule could cause in practice. He developed ways to classify rule as tyrannical, defining and outlining its various types, so that once a tyrant is removed from power, its legal consequences can be examined, including whether legal acts committed during tyranny are valid.

The aim of this article is to analyse the tacit and disguised tyranny presented in the treatise De tyranno, to identify its essential characteristics and point out the features that distinguish it from manifest tyranny. The analysis covers the types of tyranny, the ways of hiding a tyrant, threats to rights and freedoms in the case of hidden tyranny, methods of exposing the hidden tyrant, ways of eliminating tyranny, and the validity of actions performed during tyranny. The examination of these aspects is intended not only to allow an understanding of Bartolus' conception, but also to provide an answer to the question of the purpose singling out this form of tyranny serves.

A veiled tyrant is one who rules a community against the law, hiding this fact behind some sort of veil. As a legal category, the distinction between tyranny ex defectu tituli and ex parte exercitii is fundamental. The distinction between a manifest and hidden tyrant does not have such far-reaching consequences. Tacit and veiled tyranny are sometimes treated as transitional categories. On many
\end{abstract}


points, the comments applicable to manifest tyrants also apply to veiled tyrants. The purpose of distinguishing this category is to make the problem clearer - to state that a tyrant is also someone who seemingly has nothing to do with power or has little authority. Bartolus undertook to define and characterise this form of tyranny, indicating the legal instruments that could be used to deal with the undesirable political phenomenon as long as it had not yet assumed its mature form. The jurist considered it expedient to distinguish the category of a hidden tyrant so that they could be identified and held accountable under the law, although they did not formally possess any power or had very little of it, as a usurper or as one guilty of harming citizens.

Keywords: tyranny, tyrant, tacit and veiled tyranny, Bartolus de Saxoferrato, treatise.

Europa bez wątpienia wydała na świat potwory: tym samym musiała też stworzyć teorie, które pozwalają o nich myśleć i je zniszczyć.

Pascal Bruckner*

\section{Wprowadzenie}

Pytanie o koncepcję dobrego państwa i najlepszą formę rządów, stanowiące jeden z powracających tematów w filozofii politycznej, należy do kwestii ciągle aktualnych. Na przeciwległym biegunie od dobrych rządów tradycyjnie stoi tyrania $^{1}$, zjawisko, które może przybierać różne oblicza ${ }^{2}$. Ten chętnie podejmowany przez przedstawicieli średniowiecznej ${ }^{3}$ i nowożytnej doktryny filozoficznej oraz teologicznej temat znalazł swój wyraz również w nauce prawa. W tym ostatnim zakresie na uwagę zasługuje twórczość Bartolusa de Saxoferrato, uczonego jurysty będącego zarówno teoretykiem, jak i praktykiem prawa, który w dobie ius

* P. Bruckner, Tyrania skruchy. Rozważania na temat samobiczowania Zachodu, przeł. A. Szeptycki, Warszawa 2019, s. 39.

${ }^{1}$ Arystoteles stwierdził, że najgorszą formą ustroju jest niewątpliwie tyrania; idem, Polityka, przeł. L. Piotrowicz, Warszawa 2006, IV, 2 (1289 b 2).

2 Charakterystykę tyranii w ciągu dziejów obszernie przedstawił, wskazując jej elementy wspólne, M. Turchetti, Tyrannie et tyrannicide de l'Antiquité à nos jours, Paris 2013. Tam też dalsze pozycje bibliograficzne. O innych, będących zaprzeczeniem ideału politycznego pokrewnych formach zob. M. Richter, A Family of Political Concepts: Tyranny, Despotism, Bonapartism, Caesarism, Dictatorship, 1750-1917, „European Journal of Political Theory” 4, 2005 nr 3, s. 221-248; M. Turchetti, 'Despotism' and 'Tyranny' Unmasking a Tenacious Confusion, „European Journal of Political Theory" 7, 2008, nr 2, s. 159-182.

3 O tyranie i tyranobójstwie w myśli średniowiecza przykładowo zob. M. Łuszczyńska, Pojęcie tyranii w myśli średniowiecza, „Studia nad Autorytaryzmem i Totalitaryzmem” 36, 2014, nr 1, s. 7-22; J. Nikodem, Władca idealny i tyran w myśli politycznej średniowiecza, „Czasopismo Prawno-Historyczne" 71, 2019, nr 3, s. 24-42; C.J. Nederman, Three Concepts of Tyranny in Western Medieval Political Thought, „Contributions to the History of Concepts” 14, 2019, nr 2, s. 1-22. 
commune zdobył szczególny prestiż, pozycję i prymat ${ }^{4}$. Obok twórczości ściśle prawniczej, na którą składają się komentarze do poszczególnych części Corpus iuris civilis, jest on autorem traktatów o charakterze polityczno-prawnym ${ }^{5}$, poruszających istotne dla mieszkańców późnośredniowiecznej Italii tematy. Dzięki De regimine civitatis, Tractatus de Guelphis et Gebellinis oraz De tyranno Bartolus zyskał miejsce także w historii idei politycznych ${ }^{6}$. Traktaty te powstawały w czasie głębokiego kryzysu systemów miejskich czy nawet transformacji

${ }^{4}$ Literatura na temat życia i twórczości Bartolusa jest niezwykle obszerna. Przykładowo można wskazać: C.N.S. Woolf, Bartolus of Sassoferrato: His Position in the History of Medieval Political Thought, Cambridge 1913; J.L.J. van de Kamp, Bartolus de Saxoferrato, 1313-1357: Leven, Werken, Invloed, Beteekenis, Amsterdam 1936; F. Calasso, Bartolo da Sassoferrato, [w:] Dizionario biografico degli Italiani, t. 6, Roma 1964, s. 640-669; P. Weimar, Bartolus de Saxoferrato (1313/14-1357), [w:] Juristen: Ein biographisches Lexikon von der Antike bis zum 20. Jahrhundert, red. M. Stolleis, München 1995, s. 67-68; H. Lange, M. Kriechbaum, Römisches Recht im Mittelalter, t. 2. Die Kommentatoren, München 2007, s. 682-733; R. Wojciechowski, Bartolus de Saxoferrato, 1313/1314-1357, [w:] Wybrane problemy nauki i nauczania prawa, red. E. Kozerska, P. Sadowski, A. Szymański, Opole 2010, s. 121-130; G. Murano, [w:] Autographa, I.1. Giuristi, giudici e notai (sec. XII-XVI med.), Bologna 2012, s. 66-71; S. Lepsius, Bartolo da Sassoferrato, [w:] Dizionario biografico dei giuristi italiani (XII-XX secolo), t. 1, Bologna 2013, s. 177-180; O. Condorelli, Bartolo da Sassoferrato (1313/14-1357), [w:] Law and the Christian Tradition in Italy. The Legacy of the Great Jurists, red. O. Condorelli, R. Domingo, London 2020, s. 160-178.

5 Zob. F. Calasso, Gli ordinamenti giuridici del Rinascimento medievale, Milano 1965, s. 262.

6 Szczęśliwie mamy do dyspozycji wydanie krytyczne tych trzech traktatów: D. Quaglioni, Politica e diritto nel Trecento italiano. Il "De tyranno" di Bartolo da Sassoferrato (1314-1357), con l'edizione critica dei trattati "De Guelphis et Gebellinis", "De regimine civitatis" e "De tyranno”, Firenze 1983. Owe trzy ważne dla średniowiecznej europejskiej kultury prawnej traktaty powstały prawdopodobnie w ostatnich latach życia Bartolusa, między rokiem 1355 a 1357. Chronologicznie pierwszy był „Traktat o Gwelfach i Gibelinach”, w którym podniesiony został problem istnienia i legalności stronnictw miejskich, a także ich prawa do oporu wobec tyrańskich rządów. Frakcje były legalne, pod warunkiem że ich działanie miało na celu ochronę dobra wspólnego. Realizacja wyłącznie partykularnych interesów i próba obalenia prawowitego i dobrego rządu czyniła je bezprawnymi. W De regimine civitatis Bartolus podjął mający długą tradycję temat form rządów. Poddał w nim analizie kolejno trzy kwestie: Ile jest form rządów? Który z nich jest najlepszy? Który z nich jest najgorszy? Tym samym rozpoczął rozważania na temat tyranii. Osvaldo Cavallar wysnuł hipotezę, że traktaty te wraz z innym traktatem, Tractatus de fluminibus seu Tyberiadis, stanowiły większy projekt poświęcony polityce i praworządności w miastach Umbrii i Lacjum. Zob. O. Cavallar, River of Law: Bartolus's Tiberiadis (De alluvione), [w:] A Renaissance of Conflicts: Visions and Revisions of Law and Society in Italy and Spain, red. J. A. Marino, T. Kuehn, Toronto 2004, s. 31-82; idem, Geografia della tirannide. Una proposta di lettura per alcuni degli ultimi trattati bartoliani, [w:] Della tirannia. Machiavelli con Bartolo: atti della giornata di studi, Firenze, 19 ottobre 2002, red. J. Barthas, Firenze 2007, s. 4 n. W korpusie Bartolusa znajdują się także inne traktaty poruszające aspekty polityczne z punktu widzenia prawa: Tractatus represaliarum - o stosowaniu odwetu jako środka samopomocy oraz Tractatus bannitorum — o skazaniu na wygnanie z powodów politycznych, często wykorzystywanym jako instrument walki między frakcjami miejskimi. O traktatach Bartolusa, a także o traktatach mu przypisywanych zob. M.A. Panzanelli Fratoni, Le prime edizioni a stampa dei trattati di Bartolo (1472-1500). Una presentazione, [w:] Bartolo da Sassoferrato e il Trattato sulla tirannide, red. G. Crinella, Sassoferrato 2020, s. 59-87. 
ustrojowej wielu miast włoskich ${ }^{7}$. Mógł to być jednocześnie moment przemiany u samego Bartolusa, który musiał zmierzyć się z otaczającą go rzeczywistością polityczną. W jego koncepcji na straży pokoju i prawa miało stać uniwersalne cesarstwo. W rzeczywistości ta tradycyjna koncepcja władzy cesarskiej, choć ciągle w świadomości prawnej żywa ${ }^{8}$, doświadczała kryzysu na skutek pojawiania się signorii na włoskiej scenie politycznej. Pod koniec XIII wieku signoria była już typową formą ustroju wielu regionów północnych i środkowych Włoch. Bartolus, obserwując sytuację polityczną, powątpiewał, czy uniwersalne potęgi, jakimi były cesarstwo i papiestwo, są w stanie przeciwdziałać sytuacji i reformować zepsute ustroje w miastach włoskich ${ }^{9}$, utożsamiane przez niego $\mathrm{z}$ tyraniami, czemu dał wyraz w napisanym przez siebie traktacie ${ }^{10}$. Nie chcąc czy nie mogąc z nimi walczyć, w zamian za pewne korzyści, głównie natury finansowej, legitymizowały one uzurpatorów, czyniąc z nich swoich wikariuszy.

Będąc świadkiem tych wydarzeń, widząc, że „Hodie Italia est tota plena tirannis” — „Dzisiaj cała Italia jest pełna tyranów”" De tyranno ${ }^{12}$ szczegółowo zając się z tym klasycznym dla filozofii politycznej tematem ${ }^{13}$. Uczynił to $\mathrm{z}$ perspektywy prawnika zainteresowanego rozwikłaniem

7 O różnych narracjach historiograficznych i perspektywach badania historii politycznej miast włoskich w późnym średniowieczu, jak również o złożoności przestrzeni politycznej zob. A. Zorzi, La questione della tirannide nell'Italia del Trecento, [w:] Tiranni e tirannide nel Trecento italiano, red. A. Zorzi, Roma 2013, s. 11-19.

8 Zob. B. Pio, Il pensiero politico di Bartolo, [w:] Bartolo da Sassoferrato nel VII centenario della nascita: diritto, politica, società, Atti del $50^{\circ}$ Convegno storico internazionale del Centro Italiano di Studi sul basso Medioevo, Spoleto 2014, s. 175 n.

9 Zob. D. Quaglioni, Politica e diritto nel Trecento italiano, s. 57 n.

${ }^{10}$ Bartolus de Saxoferrato, Tractatus de tyranno, X. Cytaty fragmentów Tractatus de tyranno pochodzą z krytycznego wydania D. Quaglioniego zamieszczonego w Politica e diritto nel Trecento italiano. Rzymska cyfra oznacza odpowiednio jedną z dwunastu quaestiones sporządzonych przez Bartolusa, pozostałe numery są oznaczeniem wersów zastosowanym w wydaniu Quaglioniego.

11 Była to w owych czasach powszechna opinia. Tak też Dante Alighieri, Boska Komedia, Czyściec, pieśń VI, w. 124.

12 Traktat ten w rękopisach nosi różne tytuły: Tractatus De Tyrannia, Tyrannidis, De Tyranno, De Tyrannis. Autorka zdecydowała się na stosowanie w tekście artykułu tytułu De tyranno, jako że taki tytuł nosi on w edycji krytycznej D. Quaglioniego, Tractatus de Tyranno, [w:] Politica e diritto nel Trecento italiano, s. 175-213.

13 Zdaniem Jérémiego Barthasa do napisania traktatu pchnęła Bartolusa nie tyle wewnętrzna konieczność czy też moralna potrzeba prawnego rozwinięcia kwestii tyranii w ramach tradycji teologiczno-filozoficznej, sięgającej od Grzegorza Wielkiego do Tomasza z Akwinu, ile historyczna konieczność, czyli polityczna potrzeba walki z z rządem signorii i z jej jurystami przez dostosowanie do nowej sytuacji procedury rzymskokanonicznej. J. Barthas, Formes de gouvernement ou modalités de la preuve? Eclaircissements sur le Traité du tyran de Bartole de Sassoferrato, [w:] Della tirannia. Machiavelli con Bartolo: atti della giornata di studi, Firenze, 19 ottobre 2002, red. J. Barthas, Firenze 2007, s. 72. Pewne światło na motywację Bartolusa może rzucić proemium do traktatu o tyranii, przy założeniu, że jest autentyczne, a także przy uwzględnieniu jego retorycznego charakteru. Zostało ono znalezione na marginesie tylko jednego z zachowanych rękopisów traktatu (vat. lat.10726), przechowywanego w Bibliotece Watykańskiej. Zob. D. Quaglioni, Politica 
konkretnych problemów, jakie w praktyce mogły wywołać rządy tyrana ${ }^{14}$. Opracował sposoby przeprowadzania kwalifikacji prawnej danej władzy jako tyrańskiej, definiując i przedstawiając różne jej typy, by można było po odsunięciu tyrana od władzy zbadać jej konsekwencje prawne ${ }^{15}$, w tym stwierdzić ważności działań administracji miejskiej podejmowanych w czasach tyranii oraz procesów sądowych, które odbyły się pod rządami tyrana. Jak zauważył Julius Kirshner, traktat ten jest pierwszym i jedynym dziełem monograficznym napisanym przez średniowiecznego prawnika na temat tyranii ${ }^{16}$.

W analizie typologii tyranii przedstawionej przez Bartolusa znajduje się charakterystyka tyranii cichej (tacita) i zawoalowanej (velata) i jest to bodajże najbardziej oryginalna część traktatu ${ }^{17}$, w znacznej mierze inspirowanego refleksjami Arystotelesa, Tomasza z Akwinu i jego ucznia Egidiusza Rzymianina, choćby więc $\mathrm{z}$ tego względu warta przybliżenia. Bartolus czerpał inspirację, obserwując sytuację polityczną w wielu komunach włoskich, w których kapitan ludu, dowódca oddziałów wojsk najemnych czy podesta stopniowo i dyskretnie zdobywał

e diritto nel Trecento italiano, s. 12-13. Brzmi ono następująco: „Quia iam dudum in multis tractatibus laboravi dulcissimas materias pertractando, que corpus, cor et animam reddiderunt totaliter saporosam, sum adeo mellifluo sapore repletus, quod ad amaritudines, angustias et tribulationes accedere non sum ausus, maxime cum videam tyramnicam perfidiam eius robora dilatare. Tamen illius misericordie protectione confisus, qui 'linguas infantium facit diserctas', [[ymmo potius chorruscare gentibus in aperto]], audeo divino bracchio mediante tantam rigorosam et orrendam materiam tyramnice pravitatis assumere, non ut ex ea gaudium recipiam et solamen, set ut cuncti valeant a nexu et nodo illius orrende nequitie, scilicet tyramnice servitutis, seipsos penitus abolere. A cuius austero et inmoderato magisterio Deus nos liberet et in propria sancta et bona et perfecta tranquillitate conservet, nos faciat libertatis dulcedine colletari. Unde ego Bartholus de Saxoferrato, civis Perusinus, legum doctor minimus, antequam ulterius procedam circha presentem tractatum de tyramno ponam succinte aliquas questiones, quas postmodum in processu veniemus ostendendo". Dowiadujemy się z niego między innymi, że autor, który wcześniej zgłębiał przyjemne i najbardziej odpowiadające jego gustowi tematy, podejmuje wątek tyranii z niechęcią. Czyni to w chwili szczególnej, gdy „tyrańska niegodziwość” wzrasta w siłę. Ośmiela się przy boskiej pomocy podjąć tak „bezwzględny i budzący grozę temat" nie po to, by czerpać z tego radość, lecz aby wszyscy mogli pozbyć się całkowicie więzów, którymi krępuje ich tyrania. Niektórzy chcą widzieć w traktacie wezwanie cesarza Karola IV Luksemburskiego, by stanął w obronie tradycyjnych form rządów w miastach włoskich.

14 E. Emerton, Humanism and Tyranny. Studies in the Italian Trecento, Cambridge, MA 1925, s. 126. Na praktyczny aspekt traktatu kładzie nacisk także C.N.S. Wolff, Bartolus of Sassoferrato: His Position in the History of Medieval Political Thought, Cambridge 1913, s. 171-72; oraz F. Ercole, Da Bartolo al Althusio. Saggi sulla storia del pensiero pubblicistico del Rinascimento italiano, Firenze 1932, s. 315; D. Quaglioni, Il processo Avogari e la dottrina medievale della tirannide, [w:] Processo Avogari (Treviso, 1314-1315), red. G. Cagnin, Roma 1999, s. V-XXIX, http:// www.rmoa.unina.it/1078/1/RM-Quaglioni-Avogari.pdf.

15 Jak to ujął J. Barthas: „Trzeba będzie rozliczyć się z tego, co działo się podczas tyranii, i uporządkować sprawy. Oczy Bartolusa są otwarte o świcie, gdy wolni ludzie jeszcze trzeźwieją", idem, op. cit., s. 58.

16 J. Kirshner, Bartolo of Sassoferrato's De tyranno and Sallustio Buonguglielmi's Consilium on Niccolò Fortebracci's Tyranny in Città di Castello, „Mediaeval Studies” 68, 2006, s. 304.

17 Tak B. Pio, Il pensiero politico di Bartolo, s. 182. 
coraz większą władzę. Formalnie zachowując dawne prawa i urzędy, dążył do tego, by sprawować ją dożywotnio, a najlepiej przekazać spadkobiercy. Tyran tego typu podstępnie zagarnia władzę, czyniąc to w taki sposób, że współobywatele nie od razu orientują się w sytuacji, a często nawet później nie są w pełni świadomi, kto naprawdę rządzi w mieście, trudności z analizą sytuacji mają także zewnętrzni obserwatorzy ${ }^{18}$. Tyran taki jest trudny do demaskacji, a zatem niełatwy do usunięcia i ukarania. Nawet gdy fakt istnienia ukrytego tyrana jest już powszechnie znany, zwykle występują trudności w udowodnieniu, że w istocie nim jest, jako że zostają zachowane pozory wolności oraz działają stare instytucje, chociaż już pozbawione dawnego znaczenia.

Zjawisko tyranii cichej wydaje się ciekawym problemem prawnym. Niektórzy jednak nie tyle uznają ją za odrębny typ tyranii, ile raczej za etap przejściowy między ustrojem komunalnym a signorią czy też czas, w którym nakładały się na siebie ${ }^{19}$. Wcześniej czy później tyran cichy pokaże swoje prawdziwe oblicze i przekształci się w jawnego tyrana, czyli w signore del commune. Jak stwierdził Berardo Pio, kategoria tyranii cichej i zamaskowanej nie miała wielkiego szczęścia i długo była ignorowana. Autor ten wskazuje na Girolama Savonarolę jako tego, który w napisanym półtora wieku po Bartolusie Traktacie o panowaniu i rządzie miasta Florencji wykorzystał koncepcję ukrytego tyrana opracowaną przez Bartolusa ${ }^{20}$.

Celem artykułu jest analiza tyranii cichej i zakamuflowanej przedstawionej w traktacie De tyranno, uchwycenie jej istotnych właściwości oraz wskazanie cech odróżniających ją od tyranii jawnej. Jedno z zasadniczych pytań dotyczy sposobów udowodnienia istnienie tyranii zawoalowanej. Aby uzyskać na nie odpowiedź, należy przyjrzeć się, jak autor scharakteryzował zjawisko tego typu tyranii oraz jakie były jej możliwe konsekwencje. Istotnym zagadnieniem jest także to, jak Bartolus wyobraża sobie rozprawę $\mathrm{z}$ ukrytym tyranem oraz jakich wskazówek udziela w kwestii ważności czynności prawnych dokonywanych podczas rządów ukrytego tyrana. Odpowiedzi na te pytania pozwolą nie tylko zrozumieć koncepcję Bartolusa, ale być może dadzą odpowiedź na pytanie o celowość wyodrębniania tej postaci tyranii.

\section{Rodzaje tyranii}

$\mathrm{Z}$ treści zawartych $\mathrm{w}$ pierwszym i drugim pytaniu traktatu wyłania się obraz tyranii jako rządów, które nie są oparte na prawie, co może przejawiać się w dwóch głównych aspektach: w braku tytułu do sprawowania władzy oraz przez

18 Tak B. Pio, Il tiranno velato fra teoria politica e realtà storica, [w:] Tiranni e tirannide nel Trecento italiano, s. 95.

19 B. Pio, Il pensiero politico di Bartolo, s. 195.

20 Ibidem, s. 197. 
niewłaściwe sprawowanie legalnie uzyskanej władzy. Na tej podstawie Bartolus wyróżnił tyrana ex defectu tituli oraz ex parte exercitii. Zwrócił tym samym uwagę na legalność zdobycia władzy i jej sprawowania.

Tradycyjnie tyrania jest utożsamiana $\mathrm{z}$ degeneracją monarchii. Bartolus rozszerzył pojęcie tyranii na inne wynaturzone formy rządów ${ }^{21}$, podkreślając jednocześnie, że tyrania może istnieć tylko tam, gdzie wykonywana jest jurysdykcja. Odniósł się do wszystkich rodzajów tyranii, o których pisał Grzegorz Wielki, a zatem do tyrana w państwie, w pojedynczej prowincji, w mieście, w domu czy wreszcie we własnym sercu ${ }^{22}$, zastanawiał się ponadto nad tyranią in vicinia ${ }^{23}$, przez co należy rozumieć „,wszelkie formy władzy, o ograniczonych kompetencjach zarówno przedmiotowych, jak i terytorialnych, które nie posiadają autonomicznej jurysdykcji" ${ }^{24}$. Mimo że Bartolus zaznaczył, iż zajmować go będzie głównie tyrania w mieście (civitas) ${ }^{25}$, w rzeczywistości położył podwaliny pod ogólną koncepcję tyranii ${ }^{26}$.

Szczegółowe pytania o to, kim jest tyrannus civitatis i jakie mogą być jego rodzaje, padają w rozdziale piątym. Tyranem miasta jest ten, kto w mieście rządzi niezgodnie $\mathrm{z}$ prawem ${ }^{27}$. Jako że istnieją różne sposoby rządzenia sprzecznego $\mathrm{z}$ prawem, tak też są różne typy tyranó ${ }^{28}$. Jednym $\mathrm{z}$ podziałów jest podział na tyrana jawnego i oczywistego (apertus et manifestus) oraz ukrytego i cichego (velatus et tacitus). Jawnym tyranem można być przez wadę tytułu (ex defectu tituli) lub z powodu swego postępowania (ex parte exercitii) ${ }^{29}$. Tyrannus velatus jest czasem tyranem z powodu tytułu (propter titulum), gdy tylko pozornie działa legalnie, a czasem z powodu wady tytułu (propter defectum tituli) ${ }^{30}$.

Odrębną formą tyranii, o której Bartolus wspomina w pytaniu dotyczącym tyranii cichej i zakamuflowanej, jest przypadek rządzącego w mieście, który jest winien dyskryminacji niektórych obywateli, podczas gdy resztą społeczności

21 Zob. J. Baszkiewicz, Myśl polityczna wieków średnich, Poznań 1998, s. 206; J. Skomiał, Ius resistendi $w$ wiekach średnich. Zarys problematyki, ,Studia nad Autorytaryzmem i Totalitaryzmem 37, 2015, nr 2, s. 85.

22 Bartolus de Saxoferrato, Tractatus de tyranno, II.

23 Ibidem, III.

24 Bartolo da Sassoferrato, Trattati politici, s. 27, przyp. 23.

25 Ibidem, II, 103-104: ,»Alius in civitate«: de tyranno civitatis principaliter infra”.

26 D. Quaglioni, Politica e diritto nel Trecento italiano, s. 44.

27 Bartolus de Saxoferrato, Tractatus de tyranno, V, 199-200: „tyrannus civitatis est qui in civitate non iure proncipatur".

28 Ibidem, V, 200-201: „Sicut autem non iure principari multis modis contingit, ita multe sunt tyrannorum species".

29 Ibidem, V, 203-204: „Item quem esse tyrannum manifestum contingit quandoque ex defectu tituli, quandoque ex parte exercitii”.

30 Ibidem, V, 205-206: „Item eodem modo tyrannus velatus est quandoque propter titulum, quandoque propter defectum tituli”. 
rządzi w najlepszy z możliwych sposobów. W tym przypadku mógłby zostać uznany za tyrana tylko w odniesieniu do tej dyskryminowanej części ${ }^{31}$.

Jak zostało wskazane, jawnym tyranem ex defectu tituli jest ten, kto rządzi miastem bez legalnego tytułu. Może do tego dojść na kilka sposobów: przez zdobycie władzy w mieście, które nie ma praw do wybierania władzy (ius eligendi), zmuszenie obywateli siłą lub groźbą do wybrania go, nieustąpienie ze stanowiska po upływie kadencji, na którą został wybrany, przejęcie władzy po zamieszkach ${ }^{32}$.

Tyran ex parte exercicii jest „mniej właściwie” nazywany tyranem, jako że posiada on słuszny tytuł. Jest natomiast tyranem na mocy swojego postępowania, ponieważ dokonuje czynów tyranicznych, które nie są nakierowane na dobro wspólne, lecz mają na celu własną korzyść tyrana ${ }^{33}$. Dany władca wpisuje się w definicję ustaloną przez jurystę, jeżeli dopuszcza się określonych działań, uznanych za specyficzne dla tyranów, o czym będzie mowa dalej.

Bartolus rozważył także drugi typ tyrana, którego określił jako tacitus et velatus - cichy/ukryty i zawoalowany/zakamuflowany/ukryty. Jest on przeciwieństwem tyrana jawnego i oczywistego (apertus et manifestus), w takim znaczeniu, że działa w tajemnicy. Bartolus stwierdził, że tyranem ukrytym jest ten, kto rządzi w mieście pod pewnego rodzaju zasłoną i nie na mocy prawa ${ }^{34}$. Kategoria tyranii ukrytej może być z kolei podzielona na dwie dodatkowe podkategorie: propter titulum i propter defectum tituli. Tyranem ukrytym propter titulum jest ten, kto posiada mandat na określony czas, który jednak, obchodząc prawo, przedłuża. Natomiast ukryty tyran propter defectum tituli to ktoś, kto nie ma żadnego tytułu lub ma tytuł niemalże honorowy, który formalnie nie daje żadnej władzy. Tyran ukryty kryje się za zasłoną, by obejść prawo. Kluczową rolę odgrywa rodzaj owej zasłony.

\section{Rodzaje zasłon - sposoby ukrywania się tyrana}

Jak już wskazano, cichym i zawoalowanym tyranem jest ten, kto za zasłoną rządzi w mieście niezgodnie z prawem. Bartolus podaje, że zasłona ta może

31 Ibidem, XII, 761-773: „Et predicta vera, quando maior pars populi opprimitur, gravatur vel małe contentatur. Si enim aliqui extra civitatem tenerentur, vel aliqui in civitate essent male tractati, ad honores non vocati; in aliis autem civitas bene regeretur et ad communem utilitatem attenderetur: tunc talis habens talem titulum vel similem precellentiam non esset tyrannus simpliciter loquendo, quia per tale regimen communis utilitas attenditur: quod directo est oppositum tyrannidi. Sed in hiis que fierent contra extrinsecos et inimicos illius hominis sic precellentis, licet bene regat rem publicam, puto dicendum idem ac si a tyranno factum esset. Nichil enim prohibet, quod quis respectu certarum personarum dicatur tyrannus, respectu vero communitatis iustus iudex, ut $\mathrm{C}$. si quacunque preditus potestate, 1 . i. $[$ C. $5,7,1]$ ".

32 Ibidem, VI.

33 Ibidem, VIII, 458-463: „Octavo quero de tyranno manifesto ex parte exercitii, licet iustum habeat titulum, licet iste minus proprie dicatur tyrannus, ut xiiii., q. iiii., c. neque enim. [C. XIV, q. 5, c. 9] Dico quod ille tyrannus est ex parte exercitii, qui opera tyrannica facit, hoc est, opera eius non tendunt ad bonum commune, sed proprium ipsius tyranni. Istud enim est non iure principari".

34 Ibidem, XII, 656-657: „Et est ille, qui sub quodam velamine non iure principatur in civitate”. 
występować w dwóch postaciach: po pierwsze, w formie tytułu (propter titulum), który tyran sam sobie przyznał, po drugie, $\mathrm{w}$ formie odmowy przyjęcia jakiegokolwiek tytułu ${ }^{35}$.

By scharakteryzować pierwszy typ zasłony, czyli tytuł, za którym się chowa tyran, Bartolus odniósł się do cech króla, z którym tyran jest porównywany. W naturze władzy królewskiej leży jej wieczystość oraz monopol na nią. Ukrywający się tyran będzie zmierzał do tego, by jego władza pozornie nie miała tych właściwości. Z tych dwóch cech Bartolus wydedukował dwa sposoby ukrywania się tyrana propter titulum. Pierwszy miałby polegać na unikaniu ekspozycji na stanowiskach cechujących się ciągłością władzy. Będzie ukrywał się więc za fasadą obieralnych i kadencyjnych urzędów. Według tego pierwszego sposobu tyran pozwala przyznać sobie jurysdykcję na czas określony, po którego upływie następuje reelekcja. W ten sposób, jak pisze Bartolus, jego władza będzie bardziej podobna do władzy sędziego niż tyrana ${ }^{36}$. Sam fakt ponownego piastowania stanowisk może wskazywać, że mamy do czynienia z tyranem. Na potwierdzenie nieważności takiego tytułu Bartolus odwołał się do przykładów z prawa rzymskiego i kanonicznego, mówiących o kadencyjności urzędów i stanowisk: pretora, senatora i obrońcy miasta ${ }^{37}$. Dalsze wywody Bartolusa są związane z ówczesną sytuacją polityczną i jego koncepcjami ustrojowymi. Odróżnia on miasta niezawisłe (civitas sibi princeps) od miast mających nad sobą zwierzchnika, którym jest cesarz bądź papież. Przykładem tych pierwszych jest niezależna Perugia, której stał się obywatelem, tych drugich zaś miasta Ankony, skąd pochodzi1 ${ }^{38}$. Wolne miasta mają liczne uprawnienia, które w wypadku miast zależnych zarezerwowane są dla zwierzchnika: oprócz stanowienia prawa, najwyższego sądownictwa, prawa prowadzenia wojny, bicia monety i nakładania podatków należy do nich także prawo wyboru władz ${ }^{39}$. Jak pisze Bartolus, można rozważyć miasto, w którym na mocy przywileju lub zwyczaju władza ludu jest tego rodzaju, że nie można zakwestionować jego uprawnień do nadawania tytułów, a zatem pierwotnie nadany tytuł byłby ważny. Jest tak wówczas, gdy miasto nie uznaje żadnego zwierzchnika

35 Ibidem, XII, 680-682: „Istud autem velamen contingit duobus modis: primo per titulum quem sibi facit concedi; secundo per titulum quem sibi concedi non patitur". Por. ibidem, V, 205-206: „Item eodem modo tyrannus velatus est quandoque propter titulum, quandoque propter defectum tituli”. Również w ten sam sposób ktoś może być tyranem ukrytym czasem z tytułu, czasem z powodu wady tytułu.

36 Ibidem, XII, 683-690: „Circa primum velamen, per titulum quem sibi facit concedi, sciendum est, ut supra dictum est, quod tyrannus proprie opponitur regi. Sed de regia potestate est, quod sit perpetuus; item quod habeat omnem iurisdictionem, ut patet ex capitulis supra relatis. Ex hiis duobus duo velamina tyrannica inventa sunt. Primum, quod quis facit sibi concedi iurisdictionem ad tempus, et finito tempore refirmari, ut sic regimen eius magis videatur iudicis quam tyranni”.

37 Ibidem, XII, 694-697.

38 Zob. J. Baszkiewicz, Dominium mundi w pogladach politycznych Bartolusa, „Czasopismo Prawno-Historyczne" 10, 1958, $\mathrm{nr}$ 2, s. 155-161.

39 Ibidem, s. 156-157. 
— civitas sibi princeps. Należy wówczas sprawdzić, czy dana osoba nie staje się tyranem przez sam fakt bycia ponownie mianowanym po zakończeniu kadencji. Takie odnowienie jest nieważne i podpada nawet pod Lex Iulia de ambitu ${ }^{40}$. Można jednak założyć, że władza ludu jest tak wielka, że zgodnie z jego wolą istnieje możliwość powołania kogoś na kolejną kadencję. Należy wówczas się zastanowić, czy podczas pierwszej kadencji człowiek ten nie wzrósł w siłę do tego stopnia, że ludzie zostali zmuszeni do wybrania go ponownie. Wówczas byłby tyranem wybranym ze strachu, a zatem tyranem $\mathrm{z}$ braku prawowitego tytułu. Ponadto nawet jeśli zostałby wybrany dobrowolnie, mógłby okazać się tyranem w sposobie sprawowania władzy.

Co jest charakterystyczne dla tego typu tyrana, to fakt, że po zakończeniu urzędowania nie oddaje władzy, tylko ją rozszerza. Według B. Pio w przypadku tyrana propter titulum naruszenie może dotyczyć nie tylko czasu sprawowania urzędu, gdy urzędnik pozostaje na urzędzie dłużej, niż wynosi jego kadencja, lecz także przekroczenia granic wyznaczonych przez urząd, gdy urzędnik przypisuje sobie uprawnienia należące do innych podmiotów, na przykład gdy podesta rości sobie prawo do promulgowania ustaw ${ }^{41}$. Tyran ukrywa się tutaj za zasłoną pozornego respektowania zasad ustrojowych. Zasłoną jest tutaj tytuł. Wprawdzie fakt przedłużenia kadencji raczej nie mógł umknąć uwagi współobywateli, lecz mogli oni nie widzieć w tym niczego niepokojącego. Mogli sami nawet komuś dać możliwość ponownego piastowania danego urzędu, a wówczas sam ten fakt nie czynił jednostki tyranem, o ile nie zaczęła dopuszczać się tyrańskich czynów. Stopniowe naruszanie zasad ustroju jest wtedy pełzającą tyranią. Tyran najpierw kryje się za fasadą legalności, w cieniu dostojnych tradycyjnych instytucji, by później w odpowiednim czasie ukazać swoje prawdziwe zamiary — jednowładztwo w celu realizacji własnych korzyści różnej natury i interesów swoich popleczników. Konflikt interesów jest wówczas nieunikniony i aby osiągnąć swoje cele, a także utrzymać władzę, tyran dopuszcza się opera tyrannica.

Drugi rodzaj zasłony związanej z przyjęciem tytułu (propter titulum) polega na przyjmowaniu takiego tytułu, który nie wiązał się z prawie żadną władzą. Przyjąwszy go, człowiek ten mógł wówczas argumentować, że nie jest tyranem, ponieważ tyran powinien mieć pełną jurysdykcję podobnie jak król, gdy

40 Bartolus de Saxoferrato, Tractatus de tyranno, XII, 702-707: „Sed si poneres civitatem habere ex privilegio vel consuetudine, taliter quod potestas populi concedentis non posset in dubium revocari, et sic titulus valeret primo loco concessus: tunc videndum est, an ex eo quod facit se refirmari tyrannus sit. Quod videtur de iure communi, quia talis refirmatio non valet, ymmo incidit in legem Iuliam ambitus, ut C. ad legem Iuliam de ambitu, 1. i. [ C. 9, 26, 1]". W tym miejscu Bartolus powołał się na fragment Kodeksu Justyniana - C. 9, 26, 1: „Nullus omnino principatum vel numeratum seu commentariensis gradum vel cetera officia repetere audeat, cum publicae disciplinae semel gesta sufficiant. 1. Ac si quispiam promotorum denuo ad munus etiam per sacras litteras inrepserit, quod ante docebitur gessisse, cassatis quae hoc modo sunt impetrata, ad solutionem debiti primitus artetur, et qui contra fecerint poenam deportationis ad instar legis Iuliae ambitus excipiant".

41 B. Pio, Il tiranno velato fra teoria politica e realtà storica, $\mathrm{s} .98$. 
tymczasem on nie posiada prawie żadnej władzy. Jako przykłady Bartolus wymienił tytuły chorążego lub gonfaloniera, obrońcę miasta, kapitana najemników lub żołnierzy ${ }^{42}$. Jak napisał autor traktatu:

Nie można powiedzieć, że rządzi ten, kto nie ma jurysdykcji lub ma ją w niewielkim stopniu. Tytuł ten z pewnością nie czyni go tyranem, gdy jednak w wyniku tego osiągnie taką władzę, że będzie rozporządzał urzędami w mieście wedle swego uznania, a urzędnicy będą mu posłuszni jak panu, wtedy twierdzę, że jeśli on sam popełnia lub powoduje, że inni popełniają czyny tyrańskie, to jest on prawdziwym tyranem. On bowiem rzeczywiście rządzi w mieście, ponieważ władze są mu posłuszne; nie rządzi on jednak zgodnie z prawem, gdyż dopuszcza się czynów tyrańskich ${ }^{43}$.

Kolejny rodzaj zasłony polega na tym, że tyran odmawia przyjęcia jakiegokolwiek tytułu, podczas gdy w rzeczywistości zarządza sprawami miasta w taki sposób, że wszystko przebiega zgodnie z jego wolą ${ }^{44}$. Tyran tego typu nie potrzebuje żadnej oficjalnej funkcji ani tytułu, by wpływać na sytuację w mieście.

\section{Zagrożenia praw i wolności w przypadku ukrytej tyranii}

Czynami tyranicznymi Bartolus nazywa działania skierowane nie na dobro wspólne, lecz na własną korzyść. Dokonujący ich władca w istocie rządzi niezgodnie $\mathrm{z}$ prawem ${ }^{45}$. Jurysta jednak $\mathrm{w}$ innym miejscu realistycznie stwierdza, że nie istnieje władza, która skupia się wyłącznie na dobru wspólnym ${ }^{46}$. Jego zdaniem w naturze człowieka leży dbanie o własne dobro, co często odbywa się ze szkodą dla innych. Jeżeli jednak korzyść własna przeważa nad interesem zbiorowości, mamy do czynienia z tyranią, która jest ewidentna, gdy rządzący uciska poddanych, co może robić na różne sposoby.

Czynów tyranicznych może dopuszczać się lub je inicjować także ukryty i zamaskowany tyran. Wówczas jest tyranem ze względu na sposób postępowania i uwagi dotyczące jawnego tyrana ex parte exercitii odnoszą się także do niego.

42 Bartolus de Saxoferrato, Tractatus de tyranno, XII, 689-694: „Secundum velamen est, quod quidam tyranni faciunt sibi fieri aliquem titulum, cui nulla quasi iurisdictio inest: ut quia faciunt se creari vexilliferos seu confalonerios, vel faciunt sibi committi custodiam civitatis, vel faciunt se fieri capitaneos stipendiariorum vel gentis armigere; et ex hoc dicunt se non esse tyrannos, cum ad tyrannum debeat spectare omnis iurisdictio, sicut ad regem".

43 Ibidem, XII, 694-701: „Non enim potest dici principari, qui nullam vel modicam iurisdictionem habet. Certe ex isto titulo tyrannus non est. Sed ex hoc quandoque in tantam venit potentiam, quod officia civitatis ordinat prout vult, et officiales ei obediunt ut domino: tunc dico, quod si opera tyrannica facit vel fieri facit, vere tyrannus est. Nam principatur in civitate, cum regimina ei obediunt; et non iure principatur, quia opera tyrannica facit. Et sic tyrannus est".

44 Ibidem, XII, 757-759: „Tertium velamen est, quando quis nullum titulum in civitate sibi concedi patitur, sed regimina civitatis ita ordinat, quod omnia procedunt secundum velle suum".

45 Ibidem, VIII, 447-449: „Dico quod ille tyrannus est ex parte exercitii, qui opera tyrannica facit, hoc est, opera eius non tendunt ad bonum commune, sed proprium ipsius tyranni. Istud enim est non iure principari”.

46 Ibidem, XII, 749-751. 
Bartolus w pytaniu ósmym podaje katalog opera tyrannica, mając na względzie ułatwienie sposobu dowodzenia tyraniii ${ }^{47}$. Katalog ten opiera się na czynach wymienionych w Polityce Arystotelesa ${ }^{48}$ oraz przez Egidiusza Rzymianina w księdze De regimine principum ${ }^{49}$, napisanej, gdy był wychowawcą Filipa IV Pięknego, który nota bene później bezwzględnie rozprawił się z zakonem templariuszy. Katalog ten obejmuje dziesięć grup tyrańskich postępków ${ }^{50}$ :

1. Tyran dopuszcza się zabijania wybitnych i potężnych ludzi (excellentes et potentes homines), aby nie wzniecali buntu przeciwko niemu. Nie oszczędza nawet swoich braci i krewnych, co jest oznaką najgorszego rodzaju tyranii.

2. Eliminuje ludzi mądrych, aby nie ujawniali jego nieprawości i nie podburzali ludzi przeciwko niemu.

3. Niszczy edukację i naukę, nie tylko pozbywając się ludzi uczonych, ale starając się zapobiec kształceniu nowych. Czyni tak z obawy przed krytyką ze strony ludzi wykształconych.

4. Z obawy przed powstaniem przeciwko niemu, zakazuje prywatnych stowarzyszeń i publicznych spotkań, nawet tych zgodnych z prawem.

5. Ma również w całym mieście informatorów, którym chętnie daje posłuch. Wie bowiem, że jego działalność nie jest zgodna z prawem i nieustannie obawia się spisków przeciwko swojej osobie.

6. Stara się utrzymać miasto w stanie podziału, tak aby żadna frakcja, obawiając się innej, nie zbuntowała się przeciwko niemu.

${ }^{47}$ Ibidem, VIII, 449-452: ,Sed ut modus probandi facilius habeatur ad actus magis particulares descendamus, qui actus ponuntur in magna parte supra in primo libro huius tractatus: qui actus consistunt in hoc, quod subditos affligat".

48 Arystoteles, op. cit., s. 163-164, V, 9, 2 (1313 a-b).

49 Aegidius Romanus, De regimine principum, III, 2, 10, Venetiis 1498, s. 104v-105v. Zob. O. Ranum, Giles of Rome on Tyranny in His Regime of Princes, [w:] Tyranny from Ancient Greece to Renaissance France, London 2020, s. 55-56.

50 Bartolus de Saxoferrato, Tractatus de tyranno, VIII, 455-482: „Primo tyranni est excellentes et potentes homines civitatis perimere, ne contra ipsum possint insurgere. Videmus etiam quod proprios fratres et consanguineos occidunt, quod signum est pessime tyrannidis. Secundo quod sapientes destruunt, ne cognoscentes eorum mala opera arguant et populum contra eos provocent. Tertio quod disciplinam et studium perimunt. Non solum enim sapientes perimunt, sed etiam operantur ne fiant. Semper enim timent per sapientiam reprehendi. Quarto quod sodalitates et congregationes etiam licitas non permittunt: timent enim ne contra ipsos insurgant. Quinto quod habent per civitatem multos exploratores. Cum enim cognoscant se male agere, semper credunt quod de eis homines male loquantur et contra eos machinentur, et ex hoc tales relatores libenter audiunt. Sexto quod tyrannus nititur conservare civitatem in divisione, ut quelibet partium timens de alia contra eum non insurgat. Septimo quod procurat subditos facere pauperes, ut sic occupentur circa curam eorum unde vivant, ut contra eum non cogitent aliquid machinari. Octavo quod procurat bella et mittere bellatores ad partes extraneas, ita quod intenti ad illa non cogitent contra eum, et quia propter bella homines depauperantur et a studiis avocantur: quod tyrannus querit; et etiam ut habeat bellatores pro se, quando expedit. Nono quod custodiam sui non facit per cives suos, sed per forenses: timet enim de civibus. Decimo cum in civitate sunt partes, adheret uni et cum illa affligit aliam”. 
7. Celowo utrzymuje swoich poddanych w ubóstwie, aby ci byli w pełni zaabsorbowani zdobywaniem środków do życia i nie mieli czasu na spiski przeciwko niemu.

8. Wywołuje wojny i dba o to, aby wysłać żołnierzy do miejsc oddalonych od miasta, tak aby pochłonięci tymi wojnami nie knuli intryg przeciwko niemu. Wojny dodatkowo powodują to, czego pragnie tyran: zubażają ludzi i odwracają ich od studiów oraz nauki. To nie koniec korzyści z wojen dla tyrana, w ten sposób ma do swojej dyspozycji zaprawionych w bojach żołnierzy, których w razie potrzeby może użyć do swych niecnych celów.

9. Jego straż przyboczna nie jest złożona z obywateli miasta, lecz z cudzoziemców, gdyż tych pierwszych się obawia.

10. Gdy w mieście pojawiają się frakcje (partes), zawsze popiera jedną $\mathrm{z}$ nich, aby rozbić drugą.

Bartolus dokonuje jednak relatywizacji tych czynów. W jego oczach nie zawsze są one naganne, jak jest z punktu widzenia filozofii moralnej. Czasami ich dokonywanie wynika $\mathrm{z}$ konieczności. To samo działanie może stanowić czyn tyrański lub nim nie być, w zależności od tego, kogo dotyczy i jaki jest jego cel. Bartolus, mając na względzie rozwiązywanie w przyszłości przypadków praktycznych, które wymaga zbadania postępowania oskarżanej o tyranie jednostki, przeanalizował katalog, by podać przykłady wyłączenia odpowiedzialności ${ }^{51}$. Dla przykładu jurysta stwierdził, że pozbywanie się wybitnych jednostek czy nawet członków rodziny jest aktem tyranii, co jest prawdą, o ile nie zachodzi jakaś słuszna przyczyna, jak w przypadku Romulusa i Remusa ${ }^{52}$. Bartolus, powołując się na fragment Digestów justyniańskich, dał do zrozumienia, że nawet bratobójstwo może być usprawiedliwione, jeżeli jest karą za przestępstwo i odbywa się $\mathrm{w}$ interesie państwa ${ }^{53}$. Innym przykładem jest zatrudnienie wielu informatorów. Podczas gdy tyran używa ich przeciwko tym, którzy w jego ocenie mogą

51 Zob. J. Barthas, op. cit., s. 62-63.

52 Bartolus de Saxoferrato, Tractatus de tyranno, VIII, 484-491. „Primum, excellentes et fratres perimere est actus tyrannicus: verum est, nisi ex iusta causa, ut fecit Romulus de Remo, ut 1. finali ff. de rerum divisione [D. 1, 8, 11]. Quis enim dubitat, quod si aliquis esset in civitate potens, rixosus et seditiosus, iste debeat de civitate expelli a quolibet iusto iudice?, ut ff. de penis, 1. capitalium, §. solent [D. 48, 19, 28, 3], et 1. si quis aliquid, §. auctores [D. 48, 19, 38, 2]; et de officio prefecti urbi, 1. i., §. finali [D. 1, 12, 1, 14]. Tunc cum iusta causa fieret, non esset actus tyrannicus".

53 W tym miejscu jurysta odsyła do Digestów: D. 1, 8, 11: „Pomponius libro secundo ex variis lectionibus. Si quis violaverit muros, capite punitur, sicuti si quis transcendet scalis admotis vel alia qualibet ratione. Nam cives Romanos alia quam per portas egredi non licet, cum illud hostile et abominandum sit: nam et Romuli frater Remus occisus traditur ob id, quod murum transcendere voluerit”. (,Jeśli ktoś pogwałciłby mury, karany jest śmiercią, jak na przykład gdy ktoś przechodzi [przez mur] po przystawionej drabinie albo w inny sposób. Bowiem obywatelom rzymskim nie wolno wychodzić inaczej niż przez bramy, ponieważ jest to wrogie i należy się tego wystrzegać: mówi się, że i brat Romulusa, Remus, został zabity dlatego, że chciał przekroczyć mur”, A. Tarwacka, O podziale rzeczy i ich przymiotach: 8 tytut 1 księgi Digestów. Tekst - tlumaczenie - komentarz. „Zeszyty Prawnicze” 9, 2017, nr 2, s. 371 oraz komentarz do fragmentu: s. 375). 
zaszkodzić jego pozycji, władca sprawiedliwy czyni to w celu zgodnym z prawem i w interesie całej społeczności, czyli na przykład aby wykrywać przestępstwa i ścigać ich sprawców ${ }^{54}$.

Wśród wskazanych opera tyrannica Bartolus wymienił te, które uznał bezwzględnie za działania tyrańskie. Należy do nich dążenie do utrzymania miasta w stanie podziału (jest to bezwzględnie działaniem tyrańskim, gdyż podstawowym obowiązkiem sprawiedliwego władcy jest zachowanie pokoju wśród obywateli), celowe utrzymywanie poddanych w ubóstwie (co również jest bezwzględnie tyrańskim aktem, bo prawy władca nie powinien przyjmować niczego ponad to, co mu się należy, ani też obciążać poddanych ciężarami na ich osobach lub dobrach), wspieranie jednej frakcji przy jednoczesnym thumieniu drugiej (co także jest bezwzględnie aktem tyranii, ponieważ ostatecznym celem obywatelstwa, jak już powiedziano, jest spokój i pokój obywateli) ${ }^{55}$. Na koniec Bartolus stwierdził, że wszystkie te akty wskazują na istnienie tyranii, ale szczególną uwagę należy zwrócić na dwa aspekty: utrzymywanie miasta w podziale, zubożenie poddanych oraz szkodzenie ich osobom i własności ${ }^{56}$.

\section{Dowody na istnienie tyranii ukrytej}

Niejednoznaczność władzy w przypadku ukrytej tyranii sprawia, że niezwykle trudno udowodnić jej istnienie, a w dalszej kolejności osądzić ją i wyeliminować oficjalnymi metodami, które prawo przewiduje w przypadku tyranii jawnej. Żeby całemu procesowi zapewnić szansę na powodzenie, Bartolus ustalił katalog dowodów służących temu celowi.

54 Bartolus de Saxoferrato, Tractatus de tyranno, VIII, 505-510. „Quintum, scilicet quod habent in civitate multos exploratores: hic potest esse actus iusti rectoris, si ad debitum finem fiat, ut ff. de officio prefecti urbi, 1. i., §. penultimo [D. 1, 12, 1, 13]. Rectus enim iudex habet exploratores, ut corrigat delicta et alia que iniuste fiunt in civitate. Tyrannus vero habet exploratores eorum, per quos status eius posset ledi: omnia enim refert ad propriam utilitatem".

55 Ibidem, VIII, 511-521, 537-539: „Sextum, quod tyrannus studet conservare civitatem in divisione hic est simpliciter actus tyrannicus, quoniam ad iustum iudicem principaliter spectat quies civium, ut 1. i., §. quies, ff. de officio prefecti urbi [D. 1, 12, 1, 12]; et de officio presidis, 1. congruit in principio [D. 1, 18, 13]; et in aut. de mandatis principum, deinde conveniens [Nov. 17, 4, 2], ubi hoc magis expresse ponitur. Septimum, quod procurat subditos facere pauperes: hic est simpliciter actus tyrannicus. Nam rectus iudex nichil preter sibi debitum accipere debet nec subditos affligere gravaminibus realibus vel personalibus, ut C. ad legem Tuliam repetundarum, 1. iubemus [C. 9, 27, 4], et 1. finali [C. 9, 27, 6], et in aut. de mandatis principum, illud tamen [Nov. 17, 4, 9] [...] Decimum, adherere uni parti et opprimere aliam actus tyrannicus est simpliciter, cum ultimus finis civilitatis sit quies et pax civium, ut dictum est".

56 Ibidem, VIII, 540-543: „Omnia ergo predicta sunt signa ad probandum tyrannidem, sed principaliter illa duo, scilicet conservare civitatem in divisione et depauperare subditos et eos affligere in personis et rebus $[\ldots] "$ ". 
Aby zdemaskować tyrana, należy przyjrzeć się jego postępowaniu. Najpierw należy zwrócić uwagę na to, czy bardziej kieruje się on własnym interesem, czy dobrem ogółu. Jurysta ma świadomość, że rząd, który dąży wyłącznie do dobra publicznego i w którym nie ma elementu tyranii, zdarza się bardzo rzadko. Bartolus zaznacza, że podąża w tym miejscu tropem Egidiusza Rzymianina (myśl ta ma jednak wcześniejszy rodowód), według którego dobrym, a nie tyrańskim, rządem można nazwać ten, w którym interes publiczny przeważa nad interesem władcy; z drugiej strony rządem tyrańskim nazywamy ten, w którym przeważa jego interes osobisty ${ }^{57}$.

Omawiając przypadek cichego tyrana, który przybrał tytuł niedający mu prawa do jurysdykcji lub dający ją w niewielkim stopniu, Bartolus stwierdził, że dowód ze świadków nie będzie miał tu większego zastosowania, ponieważ tyran tego typu postępuje bardzo ostrożnie, nie działa we własnym imieniu, posługuje się zaufanymi ludźmi lub wysyła pisemne instrukcje i rzadko pojawia się w oficjalnym ośrodku władzy. Nie ma więc świadków jego aktywności, którzy chcieliby zeznawać, co sprawia, że dowód jest trudny ${ }^{58}$. Również przysięga (iuramentum) nie będzie miała zastosowania we wszystkich przypadkach ${ }^{59}$. $\mathrm{Z}$ tego powodu Bartolus uważa, że tyranii należy dowodzić w inny sposób, stosując mianowicie dowód pośredni. Jak wiadomo, niektórych faktów nie można udowodnić bezpośrednio, można je jednak wywnioskować na podstawie ich skutków. Jako przykłady takiego wnioskowania podaje aluwium i poczęcia dziecka. Chociaż nie widać, jak wody rzeczne transportują osady, to jednak z końcowego rezultatu można wnioskować, że naniosła je rzeka ${ }^{60}$. Jurysta pisał o tym w Tractatus de fluminibus seu Tyberiadis ${ }^{61}$. Podobnie jeśli nawet poczęcie dziecka nie jest dostrzegalne, uważa się jednak za w pełni wystarczający dowód, że ojcem dziecka jest dany mężczyzna, jeśli mieszka z jego matką ${ }^{62}$. Taki pośredni dowód zdaniem

57 Aegidius Romanus, De regimine principum 3, 2, 1, 1.

58 Bartolus de Saxoferrato, Tractatus de tyranno, XII, 728-732: „Sed qualiter poterit hoc probari, cum talis sic velatus tyrannus per se non facit, in palatio raro intrat, sed suis scriptis et nunciis regimina obediunt? Respondeo: dura probatio est, cum quando fiunt predicta testes non vocentur".

59 Ibidem, XII, 732-737: „Et hoc considerans, decretalis in certo casu statuit probari potentiam alicuius per iuramentum, ut extra, de rescriptis, c. statutum, libro vi. [Liber Sextus, I, 3, c. 11] Sed hoc non puto generale esse. Ibi enim iurans ex hoc solum iudicem consequitur. Ei autem contra quem iuratur nullum aliud preiudicium generatur".

60 Ibidem, XII, 738-741: „Sciendum est enim, quod licet quidam actus per se directo probari non possint, probantur tamen ut dixi in libro De alluvione, que licet videri non possit cum crescit, tamen ex eo quod factum est sequitur de necessitate quod flumen attulit".

61 Bartolus de Saxoferrato, Tractatus de fluminibus seu Tyberiadis, I, de alluvione.

62 Bartolus de Saxoferrato, Tractatus de tyranno, XII, 741-744: „Item licet filii generatio non videatur, tamen pro plena probatione est, quod natus est in domo ex muliere cohabitante cum viro, ut ff. de hiis qui sunt sui vel alieni iuris, 1. filium. [D. 1, 6, 6]”. 
Bartolusa wystarczy, aby przekonać sędziego do wydania wyroku ${ }^{63}$. Analogicznie na tyranię wskazują pewne fakty, stanowiące akty tyranii, na przykład że ludność w mieście jest podzielona, że członkowie jednej z frakcji politycznych zostali wygnani, że są tam popełniane zbrodnie i wykroczenia, które pozostają bez kary, że na obywateli nakładane są ogromne ciężary lub że dzieją się podobne rzeczy, które można przypisać działaniom tyrana ${ }^{64}$. Jak zauważył Julius Kirshner, tyrańska przemoc nie musi mieć wymiaru fizycznego. Dowód na tyranię istnieje także wtedy, gdy poddani nie są w stanie swobodnie zawierać umów, na przykład gdy są zmuszani do zawierania umów, których dobrowolnie by nie zawarli ${ }^{65}$.

Gdy już dojdzie do wykazania, że w mieście popełniane są czyny, które należy zakwalifikować jako tyrańskie, można wówczas zdemaskować tyrana, wsłuchując się w opinię publiczną (fama publica $)^{66}$. Zgodnie z definicją, którą można znaleźć w „Słowniku prawa” Albericusa de Rosate (1290-1354/1360), z fama (opinią, ogólnym mniemaniem), którą należy odróżnić od plotki (rumor), mamy do czynienia, gdy całe miasto lub dzielnica albo większa ich cześć tak twierdzi lub głosi ${ }^{67}$. Fama publica ma wspierać w tym przypadku mocniejszy dowód, jakim jest domniemanie. Jeżeli zgodnie z ogólnym mniemaniem niegodziwych czynów dopuszcza się człowiek uznawany za najpotężniejszego w mieście, choć mający skromny tytuł, Bartolus jest zdania, że tyrania jest dostatecznie udowod-

${ }^{63}$ Ibidem, XII, 744-745: „Cum enim probatio sit facere fidem iudici, ista satis ad fidem iudicem adducunt".

${ }^{64}$ Ibidem, XII, 745-749: „Ita in proposito, si quis probaverit civitatem esse in divisione (est enim forte una pars expulsa) et quod in ea fiunt maleficia et enormia nec puniuntur, et quod cives multum gravantur, et similia que pertinent ad actus tyrannicos, de quibus diximus".

65 J. Kirshner, op. cit., s. 308.

66 Znaczenie opinii publicznej w dochodzeniu w sprawie tyranii ujawniają akta tak zwanego procesu Advogari, który toczył się w Treviso w latach 1314-1315. Początkowo był to proces przeciwko Artico, Guecellone i Ziliolo Tempesta, w którym chodziło o nowe opłaty pobierane u bram miasta nałożone i pobierane przez Tempestów contra honorem et statum comunis Tervisii et pactorum initorum inter dictum comune Tervisii et comune Veneciarum. Według Giampaola Cagnina sprawa wyniknęła zasadniczo z dwóch powodów. Po pierwsze, komuna jako podmiot suwerenny nie podlega żadnej władzy zwierzchniej (superiorem non recognoscens), ma wiec prawo do decydowania o własnej polityce fiskalnej. Stąd może podjąć reakcje przeciwko ingerencji jakichkolwiek innych podmiotów politycznych lub osób, którym powierzono określone funkcje, obecnych na jej terytorium, jak to miało miejsce w wypadku członków rodziny Tempesta. Ponadto u źródeł procesu G. Cagnina dostrzega wyraźne wpływy pobliskiej Wenecji, która naciskała na komunę Treviso, aby ta podjęła działania przeciwko tym, którzy szkodzą jej interesom i naruszają zawarty niedawno między nimi pokój. Zob. G. Cagnin, Introduzione storica, [w:] Processo Avogari (Treviso, 1314-1315), red. G. Cagnin, Roma 1999, s. XXXI-XCI, http://www.rmoa.unina.it/238/1/RM-Cagnin-Introduzione.pdf, s. 1. Proces z czasem przerodził się w dochodzenie w sprawie tyranii rodziny da Camino (Caminesi). Istotna część akt procesowych to zeznania świadków, a publica fama jest przedmiotem drobiazgowych pytań podczas ich przesłuchiwania. Zob. D. Quaglioni, Il processo Avogari e la dottrina medievale della tirannide, s. 7-13.

67 „Fama est, quando tota civitas, vel vicinia, vel maior pars sic dicit, vel clamat, an autem probet et in quo differrat a rumore [...]", Alberici de Rosate Bergomensis Dictionarium Iuris tam Civilis, quam Canonici, Venetiis 1601, s.v. Fama, s. 112. 
niona, takich czynów nie może bowiem popełnić nikt inny jak tylko najpotężniejszy człowiek w mieście. Stwierdzenie, że w mieście popełniane są tyrańskie czyny, w połączeniu z reputacją najpotężniejszej osoby w mieście powinny być dla sędziego wystarczającym dowodem wskazującym, kto jest tyranem ${ }^{68}$. Jurysta stwierdził, że ma duże znaczenie, czy dana osoba jest uznawana za tyrana lub ma taką reputację ${ }^{69}$. Zdaniem Bartolusa opinia dużej liczby osób może być wykorzystana jako dowód i może pogrążyć tyrana mimo braku formalnych dowodów jego winy, po których starannie zatarł ślady.

Tyrana, który chowa się, odmawiając nadania sobie tytułu, podczas gdy w rzeczywistości zarządza sprawami miasta w taki sposób, że wszystko wynika z jego woli, można zdemaskować w ten sam sposób, jak już wskazano, to jest na podstawie faktu, że w mieście dochodzi do tyrańskich czynów, ale także na podstawie informacji, że jest on najpotężniejszym człowiekiem z największą klientelą, jakbyśmy w realiach rzymskich powiedzieli, i że jest odpowiedzialny za wykonanie tu wymienionych czynów. Im więcej tyrańskich czynów jest popełnianych w mieście, tym łatwiej udowodnić fakt tyranii, ,zdeprawowany umysł tyrana" nie będzie wówczas mógł pozostać w ukryciu ${ }^{70}$.

Bartolus twierdzi, że wszystkie te środki przekonają sędziego o istnieniu tyranii i wskażą jej sprawcę. Identyfikacja cichego tyrana ma na celu ustalenie, czy ma on pewne cechy, mimo że chciałby je ukryć. Demaskacja ukrytego tyrana ma w założeniu doprowadzić do jego usunięcia.

\section{Remedium na ukrytą tyranię}

Celem traktatu Bartolusa jest nie tylko opracowanie narzędzi do zdiagnozowania tyranii, ale także podstaw i środków prawnych do jej eliminacji. Pojawienie się tyrana, czyli jednostki, która uzurpuje sobie władzę lub rządzi niezgodnie z prawem, rodzi pytanie o postawę, jaką należy wobec niego przyjąć. Odpowiedź

68 Bartolus de Saxoferrato, Tractatus de tyranno, XII, 749-754: „Item quod ille talis, qui habet illum titulum est potentior homo qui sit in civitate, et quod est publica fama quod facit predicta fieri: satis puto probatam tyrannidem. Predicti enim actus ab alio quam a predicto potentiore procedere non possunt: satis enim cum fama predicta ad fidem iudicem adducunt".

69 Ibidem, XII, 756-757: „Multum facit, quod quis tanquam tyrannus habeatur et reputetur”. Bartolus wcześniej powołał się na D. 1, 14, 3: „Barbarius Philippus cum servus fugitivus esset, Romae praeturam petiit et praetor designatus est. Sed nihil ei servitutem obstetisse ait Pomponius, quasi praetor non fuerit: atquin verum est praetura eum functum. Et tamen videamus: si servus quamdiu latuit, dignitate praetoria functus sit, quid dicemus? Quae edixit, quae decrevit, nullius fore momenti? An fore propter utilitatem eorum, qui apud eum egerunt vel lege vel quo alio iure? Et verum puto nihil eorum reprobari: hoc enim humanius est: cum etiam potuit populus Romanus servo decernere hanc potestatem, sed et si scisset servum esse, liberum effecisset. Quod ius multo magis in imperatore observandum est".

70 Ibidem, XII, 792-794: „Et multa oportet quod tempore tytannidis fiant, propter que parva mens tyran ni latere non potest et modus probandi facilis apparebit”. 
na nie zależy oczywiście od punktu widzenia i okoliczności. Można pogodzić się z sytuacją lub próbować tyrana usunąć. Jednym ze sposobów jest jego fizyczna eliminacja, rozwiązanie uznawane przez niektórych autorów nie tylko za dopuszczalne, lecz nawet za słuszne i sprawiedliwe ${ }^{71}$, które było niejednokrotnie wdrażane w praktyce - tyranobójstwo ma wszak historię długą jak sama tyrania ${ }^{72}$. Bartolus opowiedział się tutaj jednak za likwidacją tyranii na drodze prawnej ${ }^{73}$, uznając, że skoro działanie tyrana jest skierowane przeciwko prawu, wymaga reakcji opartej na prawie. Działania przeciwko tyranowi były zarezerwowane w jego koncepcji wyrażonej w traktacie De tyranno dla władzy zwierzchniej i to właśnie cesarz był moralnie i prawnie odpowiedzialny za przywrócenie dawnego porządku. Życie pod jarzmem tyranii jest jednoznaczne ze stanem niewoli dla podległego cesarzowi ludu, ma więc on obowiązek wybawienia go z tejże niewoli, jak argumentuje Bartolus $w$ traktacie ${ }^{74}$. Uznanie władzy cesarza wiązało się $\mathrm{z}$ kolei z przyjęciem mocy obowiązującej prawa rzymskiego ${ }^{75}$ i tam też należało szukać regulacji prawnych mających na celu usunięcie i ukaranie tyrana ${ }^{76}$.

Likwidacja cichej tyranii tworzyła prawdziwy problem ze względu na trudności dowodowe, gdy tymczasem w rzeczywistości politycznej miast włoskich ten typ tyranów pojawiał się niezwykle często. Tyran cichy mógł być zarówno tyranem ex defectu tituli, jak i ex parte exercitii, uwagi o sposobach pozbycia się tyrana jawnego mają więc przez analogię zastosowanie także do tego typu tyrana. Tyran, który obejmuje władzę bez prawomocnego tytułu, wyraźnie podlega lex Iulia maiestatis ${ }^{77}$. Grozi mu za to kara śmierci. Władca, który ma wyraźny tytuł,

71 Jak np. Jan z Salisbury, Policraticus, III, 15.

72 B. Pio, Il pensiero politico di Bartolo, s. 185.

73 O koncepcji obalenia tyrana przez frakcję wewnętrzną zob. Bartolus de Saxoferrato, Tractatus de Guelphis et Gebellinis, [w:] D. Quaglioni, Politica e diritto nel trecento italiano. Zob. także E. Moroni, Tirannide e resistenza in Bartolo da Sassoferrato, „Cultura giuridica e diritto vivente" 1, 2014, s. 6 n.

${ }^{74}$ Bartolus de Saxoferrato, Tractatus de tyranno, IX, 564-773: „Nono quero: si aliquis dux, marchio, comes vel baro, qui habet iustum titulum probatur tyrannus exercitio, quid debet facere superior? Respondeo: debet eum deponere, quoniam domini qui talia agunt populum detinent in servitute. Sed ad superiorem pertinet populum de servitute eripere, ut C. de officio prefecti pretorio Africe, 1. i. circa principium [C. 1, 27, 1]. Item ad superiorem spectat tyrannos deponere, ut eodem titulo, de officio prefecti pretorio Africe, 1. in nomine Domini in principio, ibi: 'fortissimos tyrannos deiecimus' [C. 1, 27, 2]".

75 J. Baszkiewicz, Dominium mundi w pogladach politycznych Bartolusa, s. 150.

${ }^{76} \mathrm{~W}$ rzeczywistości jednak, jak stwierdził Ephraim Emerton, sztywne zastosowanie rzymskiej regulacji nie było możliwe w ówczesnych warunkach politycznych. Zob. E. Emerton, Humanism and Tyranny: Studies in the Italian Trecento, Cambridge 1925, s. 144. O historyczne przykładach usuwania tyranów z miast włoskich i powodach tego zob. J.-C. Maire Vigueur, La cacciata del tiranno, [w:] Tiranni e tirannide nel Trecento italiano, s. 143-169.

77 Bartolus de Saxoferrato, Tractatus de tyranno, IX, 555-558: „Sed in quam legem incidunt tyranni et per quam legem veniunt deponendi? Respondeo: de eo tyranno qui occupat sibi absque iusto titulo, certum est quod tenetur lege Iulia maiestatis". 
ale swoim postępowaniem daje się poznać jako tyran, jak pisze Bartolus, podlega lex Iulia de vi publica, ponieważ stosuje przemoc względem poddanych, podsyca podziały w mieście, uniemożliwia sądom regularne działanie, nakłada nowe podatki i opłaty. Zastosowanie względem tego typu tyrana mają także lex Iulia de vi privata, lex Iulia de ambitu ${ }^{78}$ oraz lex vectigalia nova. Bartolus wśród kar, jakie powinny go spotkać, wymienił karę wygnania, utratę praw, które wynikają $\mathrm{z}$ ius civile, ponadto jako pozbawiony czci obywatelskiej (infamis) traci dignitas oraz iurisdictio, nie może więc obejmować żadnego urzędu ani być sędzią. Jurysta wspomina także o możliwości zastosowania nawet kary śmierci ${ }^{79}$. Stwierdza ponadto, że jeśli ci, którzy żyją pod taką tyranią, „,spiskują w jakikolwiek sposób, jawnie lub potajemnie" przeciwko cesarzowi lub jego urzędnikom, są z mocy samego prawa buntownikami cesarstwa i tracą swoje urzędy — zgodnie z nowym prawem cesarza Henryka VII ${ }^{80}$.

Nie mogąc jednakże uwolnić się od tyranów, papieże i cesarze byli skłonni dochodzić z nimi do porozumienia, mianując ich swoimi wikariuszami, jak to

78 O tym, że ten, kto staje się tyranem przez nielegalne przedłużenie kadencji, czyli tyran, który kryje się za zasłoną pierwszego typu, podpada pod Lex Iulia de ambitu, pisze Bartolus w quaestio XII, traktującej o tyranii ukrytej. Bartolus de Saxoferrato, Tractatus de tyranno, XII: „Quod videtur de iure communi, quia talis refirmatio non valet, ymmo incidit in legem Iuliam ambitus, ut C. ad legem Iuliam de ambitu, 1. i. [C. 9, 26, 1]”. Powołał się w tym miejscu na C. 9, 26, 1: „Nullus omnino principatum vel numeratum seu commentariensis gradum vel cetera officia repetere audeat, cum publicae disciplinae semel gesta sufficiant. 1. Ac si quispiam promotorum denuo ad munus etiam per sacras litteras inrepserit, quod ante docebitur gessisse, cassatis quae hoc modo sunt impetrata, ad solutionem debiti primitus artetur, et qui contra fecerint poenam deportationis ad instar legis Iuliae ambitus excipiant". Z przytoczonego fragmentu wynika zakaz ponownego ubiegania się o pewne urzędy, jako że ,jedna kadencja wystarczy dla dobra publicznego”. Ponowne zajęcie urzędu zostanie uznane za nieważne, a urzędnik będzie zmuszony do zapłacenia wszystkiego, co jest winien (z tytułu sprawowania urzędu) oraz zostanie ukarany deportacją.

79 Ibidem, IX, 558-573: „De illo vero tyranno, qui iustum habet titulum sed exercitio apparet tyrannus, dico quod ex eo quod subditos suos affligit in corpus, incidit in legem Iuliam de vi publica. Item ex eo quod civitatem tenet in divisione et sic iudicia non patitur fieri ut oportet, incidit in eandem legem, ut ff. ad legem Iuliam de vi publica, 1. qui dolo malo [D. 48, 6, 10]. Item ex eo quod novas exactiones imponit et nova vectigalia, in eandem legem incidit, ut eodem titulo, 1 . finali [D. 48.6.12], cuius legis pena est deportatio, ut Institutionibus, de publicis iudiciis, §. item lex [I. 4.18.8] Et sic amittit omnia que iuris civilis sunt, ut 1. quidam, ff. de penis [D. 48, 19, 17]; et sic tanquam infamis perdit dignitatem et iuris dictionem, ut expresse dicitur ff. ad legem Iuliam de vi privata, 1. i. in principio [D. 48, 7, 1]. Item ex hoc incidit in legem Iuliam de ambitu, ut ff. ad legem Iuliam ambitus, 1. i., §. i. [D. 48, 14, 1], et in constitutionem C. nova vectigalia, 1. finali [C. 4, 52, 4]. Item forsan incidit in penam capitalem, ut C. de superexactionibus, 1. i., libro x [C. 10, 20, 1]".

${ }^{80}$ Ibidem, IX, 574-577: „Dico etiam, quod si existentes in tali tyrannide 'quomodocunque aliquid publice vel occulte machinantur ' contra principem vel eius officiales, ipso iure sunt rebelles imperii et dignitatem perdunt, secundum legem novam Henrici imperatoris [Extravagantes Henrici VII, 2, Qui sint rebelles]". 
uczynił Klemens VI w Bolonii, cesarz Karol IV z tyranami Lombardii, Egidio Albornoz, legat Stolicy Apostolskiej, z wieloma tyranami Marchii Ankony ${ }^{81}$.

\section{Ważność czynności dokonanych w czasie trwania tyranii}

Udowodnienie faktu tyranii i usunięcie tyrana w sposób oficjalny bądź podniesienie go do rangi wikariusza nie rozwiązuje wszystkich problemów, jakie wynikają z faktu jego bezprawnego działania. Do rozważenia zostaje jeszcze ocena czynności podejmowanych w czasie, gdy sprawował władzę, co wpisuje się w większy problem ciągłości zobowiązań prawnych przy zmianie formy rządów. Bartolus, omawiając ważność czynności dokonanych przez oczywistego tyrana, któremu brakowało tytułu do sprawowania władzy (tyrannus manifestus ex defectu tituli), lub podczas jego panowania, podzielił je na kilka grup, wyróżniając czynności dokonywane $\mathrm{w}$ drodze jurysdykcji, umowy różnych rodzajów oraz akty niebędące umowami ${ }^{82}$. Pytając o ważność aktów dokonanych, podczas gdy w mieście rządził cichy tyran, jurysta odesłał do rozważań odnoszących się do tyrana jawnego. Gdy chodzi o tyrana cichego, który przybiera sobie tytuł z nieznaczną jurysdykcją, w odpowiedzi podał analogiczną opinię do tej dotyczącej oczywistego tyrana, który steruje działaniami urzędników wybranych przez miasto. Wydaje się, że akty te są nieważne na mocy lex decernimus ${ }^{83}$, mówiącym o tym, że wszystko, co zostało uczynione w czasie tyranii, jest ipso iure nieważne. Nieważne są zatem nie tylko czyny dokonane przez samego tyrana, lecz także wszelkie czyny dokonane w czasie tyranii ${ }^{84}$. Według Bartolusa uzasadnieniem jest to, że w mieście, w którym panuje tyran, żadna czynność nie jest wykonywana swobodnie, a skoro tak jest, nie ma znaczenia, czy dokonuje jej sam tyran, czy

81 Ibidem, X, 580-587. Zob. także A. Zorzi, Ripensando $i$ vicariati imperiali e apostolici, [w:] Signorie italiane e modelli monarchici, secoli XIII-XIV, red. P. Grillo, Roma 2013, s. 19-43.

82 Obszernie omówił to w siódmej quaestio.

83 C. 1, 2, 16: „Imperator Zeno. Decernimus, ut antiquatis ac infirmatis funditus, quae contra ipsum orthodoxae religionis deum quodammodo facta sunt, in integrum restituantur universa et ad suum ordinem revocentur, quae ante profectionem nostrae mansuetudinis de orthodoxae religionis fide et sanctissimarum ecclesiarum et martyriorum statu firmiter obtinebant: his, quae contra haec tempore tyrannidis innovata sunt tam contra venerabiles ecclesias, quarum sacerdotium gerit beatissimus ac religiosissimus episcopus patriarcha nostrae pietatis pater acacius, quam ceteras, quae per diversas provincias collocatae sunt, nec non et reverentissimos earum antistites seu de iure sacerdotalium creationum seu de expulsione cuiusquam episcopi a quolibet illis temporibus facta seu de praerogativa in episcoporum concilio vel extra concilium ante alios residendi vel de privilegio metropolitano vel patriarch ico sub isdem impiis temporibus, penitus antiquandis, ut cassatis et rescissis, quae per huiusmodi sceleratas iussiones aut pragmaticas sanctiones aut constitutiones impias sive formas subsecuta sunt, quae a divae recordationis retro principibus ante nostrum imperium et deinceps a nostra mansuetudine indulta vel constituta sunt super sanctis ecclesiis et martyriis et religiosis episcopis clericis aut monachis, inviolata serventur".

84 Bartolus de Saxoferrato, Tractatus de tyranno, VII. 
ktoś znajdujący się pod jego kontrolą. Jurysta kwestionował więc legalność działań tyrana i mianowanych przez niego urzędników, uznając jednocześnie czynności urzędników wybranych przez samą społeczność patiente tyranno też za nieważne, ponieważ w czasie trwania tyranii żadne wybory nie mogły być przeprowadzone swobodnie. Oprócz innego zastrzeżenia dotyczącego interpretacji lex decernimus zauważył jednak, że uznanie wszystkich czynności dokonanych przez administrację miejską za nieważne godziłoby w zasady słuszności. Okres tyranii nie może oznaczać unieważnienia z mocą wsteczną wszystkich czynności prawnych. Byłoby też nadmiernie surowe, gdyby tyrania w jakimś mieście znacznie się przedłużała ${ }^{85}$. W analizie ważności czynności dokonanych w okresie trwania tyranii Bartolus pragmatycznie uwzględnił długość jej trwania: im dłużej tyran pozostawał u władzy, tym mocniejsze było domniemanie ważności działań podejmowanych $\mathrm{w}$ owym czasie ${ }^{86}$. $\mathrm{Z}$ całą pewnością nieważne ipso iure były procesy przeciwko buntownikom i wrogom tyrana — „,nie powinni oni bowiem stawać przed sędzią jawnie im wrogim lub w miejscu jawnie wobec nich podejrzanym"87. Więcej wątpliwości miał Bartolus co do nieważności zarządzeń, postępowań i wyroków odnoszących się do mieszkańców miasta. Porównał ich do osób wolnych znajdujących się pod patria potestas lub dominica potestas, czyli pod władzą ojca rodziny lub właściciela nad niewolnikami. Jeśli osoba ta uczyniła coś świadomie, co uczyniłaby w każdym przypadku, to czynność ta jest ważna; jeśli zaś nie miałaby swobody, aby postąpić inaczej, to czynność ta jest nieważna. Jeżeli więc pewne akty są wykonywane przez sam lud podlegający władzy tyrana lub przez urzędników przez niego wybranych, o ile dokonaliby ich, nawet gdyby byli wolni od władzy tyrana, to akty te są ważne. Bartolus ma tu na myśli zwykłe sprawy sądowe, które toczą się niezależnie od rodzaju władzy w mieście, a które są podejmowane dobrowolnie przez strony. Nieważne są z kolei czynności podejmowane ze strachu przed tyranem. Jeżeli zostały one dokonane w wyniku normalnego działania urzędów i sądów, były ważne, jeśli zaś pod przymusem ze strony tyrana, można było uchylić się od tej czynności, powołując się na obawę wywołaną groźbą bezprawną (metus) ${ }^{88}$. Oprócz sankcji nieważności Bartolus

85 Ibidem, VII, 291-295: ,In contrarium, quia in dicta 1. decernimus non dicitur quod sint nulla, nisi que facta sunt contra ecclesias, ergo alia videntur remanere valida. Preterea, insurgeret iniquitas: si enim in civitate duravit tyrannides longo tempore, dicemusne omnia celebrata et acta in curia esse nulla? Durum videtur".

${ }^{86}$ E. Emerton, op. cit., s. 135.

87 Bartolus de Saxoferrato, Tractatus de tyranno, VII, 296-301: „Dico sic, quod aliqui processus fiunt contra rebelles seu inimicos tyranni et tales processus sunt ipso iure nulli. Non enim debuerunt comparere coram iudice sibi notorie inimico vel in loco sibi notorie suspecto, ut ff. ad Trebellianum, 1. de etate [D.36.1.8]; quibus ex causis in possessionem eatur, 1. Fulcinius, §. i. [D. 42, 4, 7, 1], et de legationibus, 1. sciendum [D.50.7.5]; et est expressum de re iudicata, c. pastoralis, in Clementinis [Clem. 2.11.2]".

88 Ibidem, VII, 302-316: „Quedam vero ordinamenta, sententie et processus fiunt contra ipsos intrinsecos: tunc plus dubitationis habet. Sed advertendum est, quod in homine libero qui detinetur 
dopuścił też sankcję odszkodowawczą, zgodnie z ogólnymi normami regulującymi tę kwestię w prawie rzymskim ${ }^{89}$. Zarówno osoby fizyczne, korporacje, jak i instytucje kościelne będą mogły po upadku tyranii domagać się naprawienia szkód ${ }^{90}$.

Jurysta przeanalizował także umowy zawierane przez tyrana w najróżniejszych sytuacjach, te dotyczące i prawa publicznego, i prawa prywatnego. Jeśli chodzi o umowy między tyranem a poddanymi, zgodnie z opinią Bartolusa były one nieważne. Ważność umów między tyranem a cudzoziemcami zależała od tego, czy były one korzystne dla miasta, którym władał. Jeżeli były one dla niego szkodliwe, były nieważne. Odnośnie do umów dla niego korzystnych Bartolus wykazywał pewne wahanie. Stwierdził, że prawdopodobnie też są nieważne, choć Hostiensis twierdził inaczej ${ }^{91}$.

W zakresie ważności czynności dokonanej w czasie tyranii cichej, gdy tyran nie przyjmuje żadnego tytułu, Bartolus odesłał do rozważań przedstawionych supra proxime ${ }^{92}$.

Gdy chodzi o ważność czynności tyrana mającego wprawdzie prawomocny tytuł, lecz dopuszczającego się aktów tyranii, czyli tyrana ex parte exercitii, komentator stwierdzil, że proces wszczęty przeciwko buntownikowi czy osobie wygnanej przez tyrana jest nieważny, gdyż nikt nie musi stawać przed sędzią notorycznie wrogim. Inne procesy są ważne, dopóki poddani tolerują tyrana, czyli dopóki nie zostanie usunięty. Jeśli zostanie wszczęta procedura usunięcia tyrana, należy uznać, że czynności, których dokonał po jej rozpoczęciu, są nieważne, gdy toczy się proces, w którego wyniku zostaje wydany wyrok deklaratoryjny i tyran zostaje ipso iure pozbawiony jurysdykcji. Jeśli jest to proces, w którym pozbawienie tyrana jurysdykcji ma nastąpić na mocy wyroku, to czynności dokonane w czasie, gdy toczył się proces, pozostają ważne, ponieważ wówczas jeszcze ma on ważny tytuł. Również umowy pozostają ważne tak długo, jak długo tyran sprawuje swój urząd, chyba że działają one na szkodę społeczności, którą rządzi ${ }^{93}$.

ab aliquo sub potestate patria vel dominica, si sic existens aliquid facit scienter vel quod facturus esset in omnem eventum, tunc illud valet; secus si alias facturus non esset, ut ff. de acquirendo rerum dominio, 1. liber homo, $\S$ finali [D.41.1.19], et 1. homo liber in principio [D.41.1.54], et ibi nota; et de acquirenda hereditate, 1. qui in aliena, §. i. [D. 29, 2, 6.1] Ita in proposito, quedam facit ipse populus liber nunc sub potestate tyrannica detentus vel officiales a tali populo electi, que fecissent in omnem eventum, etiam si in potestate sua libera essent, ut decisiones quatundam causarum communium, quas quilibet tyrannus patitur ire sub regulis iustitie: et tunc illa valent, quia voluntarie facta sunt. Quedam sunt, que facta non fuissent, nisi propter tyrannum: et ista non valent tanquam facta non libere, sed per metum tyranni, per iura predicta".

89 Ibidem, VII.

90 J. Kirshner, op. cit., s. 311.

91 C.N.S. Wolff, op. cit., s. 165.

92 Bartolus de Saxoferrato, Tractatus de tyranno, XII, 795-796: „De hiis autem, que fiunt tempore talis tyrannidis, dico idem quod supra proxime".

93 C.N.S. Wolff, op. cit., s. 166-7. 


\section{Podsumowanie}

Traktat Bartolusa De tyranno może być odczytywany jako naukowy tekst systematyzujący prawne aspekty tyranii lub też swoisty przewodnik dla praktyków prawa, jak za pomocą norm ius commune, którego bardzo istotnymi substratami były prawo rzymskie i kanoniczne, rozwiązywać trapiące włoskie miasta problemy powstające $\mathrm{w}$ związku $\mathrm{z}$ rządami tyranów ${ }^{94}$. Był on szeroko rozpowszechniony, o czym świadczą liczne rękopisy i wydania drukowane, wywierał także wpływ na późniejszych autorów, dokonujących teoretycznych analiz tyranii i tyranobójstwa, takich jak Jean Bodin (1530-1596), Teodor Beza (1519-1605) czy Johannes Althusius (1557-1638) ${ }^{95}$.

Tyranem w koncepcji przyjętej przez Bartolusa jest ten, kto rządzi poza granicami prawa, lecz zgodnie z własnym interesem, niezależnie od tego, czy sprawuje władzę oficjalnie. Bartolus w otaczającej go przestrzeni politycznej obserwował zjawisko pojawiania się osób, które nie będąc formalnie upoważnione do rządzenia miastem, sprawowały w nim władzę de facto. Stan ten powodował jednak konkretne konsekwencje prawne i to właśnie nimi, z racji swojego zawodu, był najbardziej zainteresowany. Tyranem ukrytym jest ten, kto rządzi społecznością wbrew prawu, ukrywając ten fakt za zasłoną pozornej zgodności z zasadami ustrojowymi.

Jako kategoria prawna rozróżnienie na tyrana ex defectu tituli i ex parte exercitii ma fundamentalne znaczenie. Różna jest podstawa oskarżenia o tyranię, różne są sankcje karne. Można być władcą sprawiedliwym, dbającym o dobro wspólne, a mimo to być tyranem, gdyż brakuje legitymacji do rządzenia. Jednak można też mieć tytuł do sprawowania władzy, a być tyranem przez dokonywanie tyrańskich czynów. Rozróżnienie na tyrana jawnego i ukrytego nie skutkuje tak daleko idącymi konsekwencjami. Tyrania ukryta i zawoalowana bywa traktowana jako kategoria przejściowa.

W wielu punktach uwagi mające zastosowanie do tyranów jawnych odnoszą się także do tyranów ukrytych. Jako przykład można wymienić zasady ważności czynności dokonanych podczas trwania tyranii, jak również fakt, że jej istnienia można dowieść w sposób analogiczny przez stwierdzenie, czy w mieście popełniane są czyny tyrańskie. Sprawcą jest najpewniej najpotężniejszy tam człowiek. Przeprowadzenie dowodu w przypadku tyranii ukrytej może być jednak o wiele trudniejsze niż w kwestii tyranii jawnej, dlatego Bartolus poświęca temu tematowi

94 Można znaleźć pewne przykłady na wykorzystanie przez prawników traktatu De tyranno w sprawach, które prowadzili. Zob. O. Cavallar, Il tiranno, i dubia del giudice, e i consilia dei giuristi, „Archivio storico italiano” 155, 1997, s. 265-345; J. Kirshner, op. cit., s. 303-331. Julius Kirshner stwierdził jednak, że rzuca się w oczy brak konkretnych przykładów roli, jaką traktat ten odegrał w procesach sądowych dotyczących czynów tyranów czy też ich urzędników, ibidem, s. 305.

95 J. Kirshner, op. cit., s. 305. 
wiele miejsca. Charakteryzując tyranię ukrytą, chciał dać możliwość zaradzenia sytuacji stworzonej przez trudno uchwytną formę tyranii.

W przypadku tyranii ukrytej wielu ludzi nie uświadamia sobie rzeczywistej sytuacji, funkcjonując w systemie tyranii bez wiedzy o tym. Bartolus przedstawia mechanizmy ochrony prawnej przed wypaczeniami władzy publicznej, także tymi, które są ukrywane. Celowość wyodrębnienia tej kategorii zasadza się na uzmysłowieniu problemu - na stwierdzeniu, że tyranem jest także ten, kto pozornie nie ma nic wspólnego $\mathrm{z}$ władzą $\mathrm{w}$ mieście lub też ma niewielki zakres kompetencji. Bartolus podjął się zdefiniowania i scharakteryzowania tej formy tyranii, wskazując instrumenty prawne mogące służyć do rozprawienia się z niepożądanym zjawiskiem politycznym, dopóki jeszcze nie przybrało ono swojej dojrzałej formy. Jurysta uznał za celowe wyodrębnienie kategorii cichego tyrana, by można go było zidentyfikować i pociągnąć do odpowiedzialności na gruncie prawa, mimo że formalnie nie miał żadnej władzy lub też miał jej niewiele, jako uzurpatora lub winnego krzywd obywateli. Ustanawiając rozróżnienie między tyranem jawnym a ukrytym, Bartolus widział to, co wielu ludziom, zmęczonym niepewną sytuacją polityczną, konfliktami i walkami, umykało lub było przez nich tolerowane, a nawet akceptowane jako najlepsze rozwiązanie dla rozdartego walkami frakcji miasta. Często widzieli oni w tyranie nadzieję na spokój i porządek, nie dostrzegając zagrożeń swych praw i wolności.

Traktat ten powstał w konkretnych okolicznościach historycznych, ale refleksje Bartolusa o tyranii niejawnej nie są ściśle związane tylko z problemami czasów Bartolusa. Problem uzurpacji władzy poza ramami konstytucyjnymi, jak również niewłaściwego jej używania pozostaje aktualny także w naszych czasach w różnych szerokościach geograficznych.

\section{Bibliografia}

Aegidius Romanus, De regimine principum, Venetiis 1498.

Alberici de Rosate Bergomensis Dictionarium Iuris tam Civilis, quam Canonici, Venetiis 1601.

Arystoteles, Polityka, przeł. L. Piotrowicz, Warszawa 2006.

Barthas J., Formes de gouvernement ou modalités de la preuve? Eclaircissements sur le Traité du tyran de Bartole de Sassoferrato, [w:] Della tirannia. Machiavelli con Bartolo: atti della giornata di studi, Firenze, 19 ottobre 2002, red. J. Barthas, Firenze 2007.

Bartolo da Sassoferrato, Trattati politici; sulla tirannide, sulle costituzioni politiche, sui partiti, przeł. A. Turrioni, red. D. Razzi, Foligno 2019.

Baszkiewicz J., Dominium mundi w pogladach politycznych Bartolusa, „Czasopismo Prawno-Historyczne" 10, 1958, nr 2.

Baszkiewicz J., Myśl polityczna wieków średnich, Poznań 1998.

Bruckner P., Tyrania skruchy. Rozważania na temat samobiczowania Zachodu, przeł. A. Szeptycki, Warszawa 2019.

Cagnin G., Introduzione storica, [w:] Processo Avogari (Treviso, 1314-1315), red. G. Cagnin, Roma 1999. 
Calasso F., Bartolo da Sassoferrato, [w:] Dizionario biografico degli Italiani, t. 6, Roma 1964.

Calasso F., Gli ordinamenti giuridici del Rinascimento medievale, Milano 1965.

Cavallar O., Geografia della tirannide. Una proposta di lettura per alcuni degli ultimi trattati bartoliani, [w:] Della tirannia. Machiavelli con Bartolo: atti della giornata di studi, Firenze, 19 ottobre 2002, red. J. Barthas, Firenze 2007.

Cavallar O., River of Law: Bartolus's Tiberiadis (De alluvione), [w:] A Renaissance of Conflicts: Visions and Revisions of Law and Society in Italy and Spain, red. J.A. Marino, T. Kuehn, Toronto 2004.

Cavallar O., Il tiranno, i dubia del giudice, e i consilia dei giuristi, „Archivio storico italiano” 155, 1997.

Condorelli O., Bartolo da Sassoferrato (1313/14-1357), [w:] Law and the Christian Tradition in Italy. The Legacy of the Great Jurists, red. O. Condorelli, R. Domingo, London 2020.

Emerton E., Humanism and Tyranny. Studies in the Italian Trecento, Cambridge, MA 1925.

Ercole F., Da Bartolo al Althusio. Saggi sulla storia del pensiero pubblicistico del Rinascimento italiano, Firenze 1932.

Kamp J.L.J. van de, Bartolus de Saxoferrato, 1313-1357: Leven, Werken, Invloed, Beteekenis, Amsterdam 1936.

Kirshner J., Bartolo of Sassoferrato 's De tyranno and Sallustio Buonguglielmi's Consilium on Niccolò Fortebracci's Tyranny in Città di Castello, „Mediaeval Studies” 68, 2006.

Lange H., Kriechbaum M., Römisches Recht im Mittelalter, t. 2. Die Kommentatoren, München 2007.

Lepsius S., Bartolo da Sassoferrato, [w:] Dizionario biografico dei giuristi italiani (XII-XX secolo), t. 1, Bologna 2013.

Łuszczyńska M., Pojęcie tyranii w myśli średniowiecza, „Studia nad Autorytaryzmem i Totalitaryzmem" 36, 2014, nr 1.

Maire Vigueur J.-C., La cacciata del tiranno, [w:] Tiranni e tirannide nel Trecento italiano, red. A. Zorzi, Roma 2013.

Moroni E., Tirannide e resistenza in Bartolo da Sassoferrato, „Cultura giuridica e diritto vivente” 1, 2014.

Murano G., [w:] Autographa. I.1 Giuristi, giudici e notai (sec. XII-XVI med.), Bologna 2012.

Nederman C.J., Three Concepts of Tyranny in Western Medieval Political Thought, „Contributions to the History of Concepts" 14, 2019, nr 2.

Nikodem J., Władca idealny i tyran w myśli politycznej średniowiecza, „Czasopismo Prawno-Historyczne" 71, 2019, $\mathrm{nr} 2$.

Panzanelli Fratoni M.A., Le prime edizioni a stampa dei trattati di Bartolo (1472-1500). Una presentazione, [w:] Bartolo da Sassoferrato e il Trattato sulla tirannide, red. G. Crinella, Sassoferrato 2020.

Pio B., Il pensiero politico di Bartolo, [w:] Bartolo da Sassoferrato nel VII centenario della nascita: diritto, politica, società, Atti del $50^{\circ}$ Convegno storico internazionale del Centro Italiano di Studi sul basso Medioevo, Spoleto 2014.

Pio B., Il tiranno velato fra teoria politica e realtà storica, [w:] Tiranni e tirannide nel Trecento italiano, red. A. Zorzi, Roma 2013.

Quaglioni D., Politica e diritto nel Trecento italiano. Il "De tyranno" di Bartolo da Sassoferrato (1314-1357), con l'edizione critica dei trattati "De Guelphis et Gebellinis", "De regimine civitatis" e "De tyranno", Firenze 1983.

Quaglioni D., Il processo Avogari e la dottrina medievale della tirannide, [w:] Processo Avogari (Treviso, 1314-1315), red. G. Cagnin, Roma 1999.

Ranum O., Giles of Rome on Tyranny in His Regime of Princes, [w:] Tyranny from Ancient Greece to Renaissance France, London 2020. 
Richter M., A Family of Political Concepts Tyranny, Despotism, Bonapartism, Caesarism, Dictatorship, 1750-1917, „European Journal of Political Theory” 4, 2005, nr 3.

Skomiał J., Ius resistendi $w$ wiekach średnich. Zarys problematyki, „Studia nad Autorytaryzmem i Totalitaryzmem" 37, 2015, nr 2.

Tarwacka A., O podziale rzeczy i ich przymiotach: 8 tytut 1 księgi Digestów. Tekst - tlumaczenie komentarz, „Zeszyty Prawnicze” 9, 2017, nr 2.

Turchetti M., 'Despotism' and 'Tyranny' Unmasking a Tenacious Confusion, „European Journal of Political Theory" 7, 2008, nr 2.

Turchetti M., Tyrannie et tyrannicide de l'Antiquité à nos jours, Paris 2013.

Weimar P., Bartolus de Saxoferrato (1313/14-1357), [w:] Juristen: Ein biographisches Lexikon von der Antike bis zum 20. Jahrhundert, red. M. Stolleis, München 1995.

Wojciechowski R., Bartolus de Saxoferrato, 1313/1314-1357, [w:] Wybrane problemy nauki i nauczania prawa, red. E. Kozerska, P. Sadowski, A. Szymański, Opole 2010.

Woolf C.N.S., Bartolus of Sassoferrato: His Position in the History of Medieval Political Thought, Cambridge 1913.

Zorzi A., Ripensando i vicariati imperiali e apostolici, [w:] Signorie italiane e modelli monarchici, secoli XIII-XIV, red. P. Grillo, Roma 2013.

Zorzi A., La questione della tirannide nell'Italia del Trecento, [w:] Tiranni e tirannide nel Trecento italiano, red. A. Zorzi, Roma 2013. 